\title{
Working
}

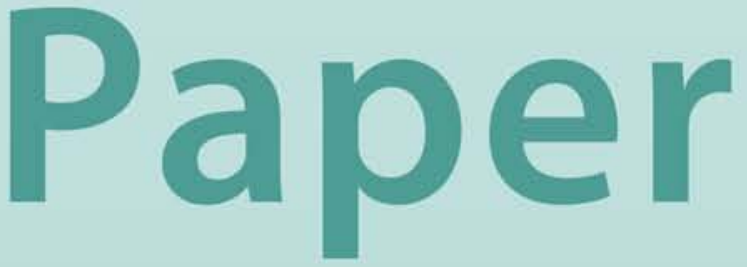




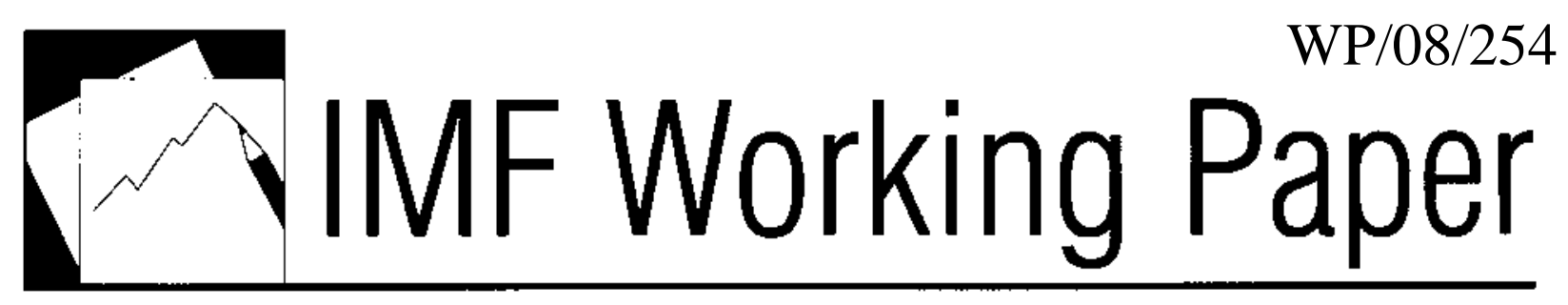

\section{Sovereign Wealth Funds: Current Institutional and Operational Practices}

Cornelia Hammer, Peter Kunzel, and Iva Petrova 


\title{
IMF Working Paper
}

Monetary and Capital Markets Department

\section{Sovereign Wealth Funds: Current Institutional and Operational Practices ${ }^{1}$}

\author{
Prepared by Cornelia Hammer, Peter Kunzel, and Iva Petrova
}

Authorized for distribution by Udaibir S. Das

November 2008

\begin{abstract}
This Working Paper should not be reported as representing the views of the IMF.

The views expressed in this Working Paper are those of the author(s) and do not necessarily represent those of the IMF or IMF policy. Working Papers describe research in progress by the author(s) and are published to elicit comments and to further debate.

While SWFs as a group share broad common institutional and operational practices, these practices also differ considerably reflecting the diversity of these institutions. These differences derive from the nature of the SWF (i.e., their original intent) as well as its legal personality. Thus, while SWF practices will continue to evolve, the fundamental objectives of different types of SWFs will continue to shape their practices going forward.

JEL Classification Numbers:F30, F50, F53, F55

Keywords: Sovereign Wealth Funds, Governance and Accountability, Investment and Risk Management

Author’s E-Mail Address:cornelia.hammer@bundesbank.de, pkunzel@imf.org, ipetrova@imf.org

\footnotetext{
${ }^{1}$ When this paper was written, Cornelia Hammer was on secondment at the IMF from the Deutsche Bundesbank. Peter Kunzel and Iva Petrova work in the Monetary and Capital Markets Department of the IMF. We are grateful for contributions and useful suggestions from colleagues of the Sovereign Wealth Fund Technical Group at the IMF and members of the International Working Group of Sovereign Wealth Funds (IWG). The usual disclaimer applies.
} 


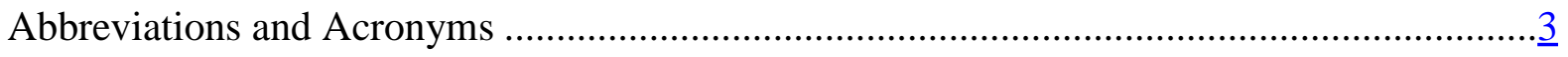

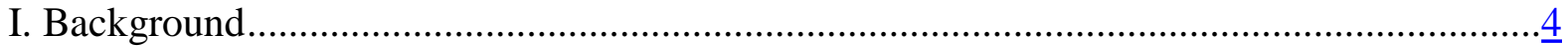

II. Legal Framework, Objectives, and Macroeconomic Linkages......................................... $\underline{5}$

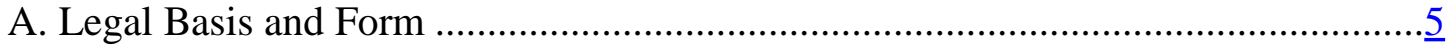

B. Objectives and Macroeconomic Linkages ..................................................... $\underline{5}$

C. Funding and Withdrawal Rules..................................................................

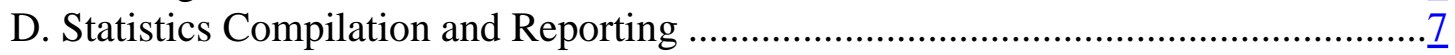

III. Institutional Framework and Governance Structure ................................................... $\underline{8}$

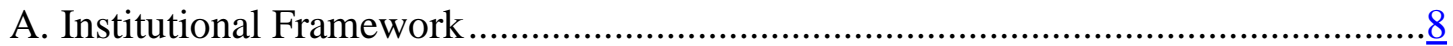

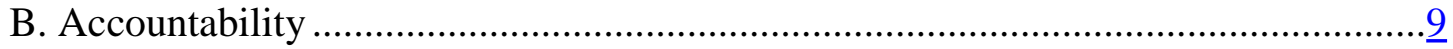

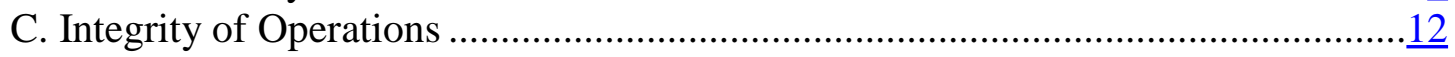

IV. Investment Policies and Risk anagement Frameworks ............................................. 14

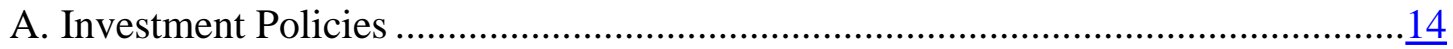

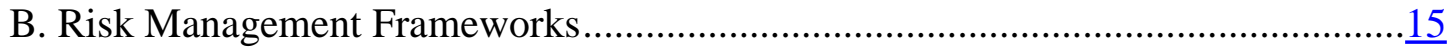

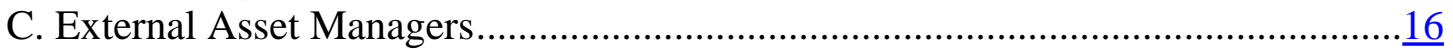

D. Other Information .......................................................................... $\frac{17}{18}$

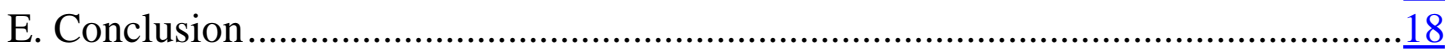

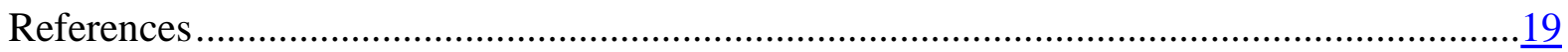




\section{AbBreviations AND ACronyms}

BOP Balance of Payments Statistics

BPM6 Sixth edition of the IMF's Balance of Payments and IIP Manual

CEO Chief Executive Officer

GAAP Generally Accepted Accounting Principles

GAPP Generally Accepted Principles and Practices

GFS Government Finance Statistics

IFRS International Financial Reporting Standards

IIP International Investment Position

IMF International Monetary Fund

IPSAS International Public Sector Accounting Standards

IWG International Working Group of Sovereign Wealth Funds

SWF Sovereign Wealth Fund 


\section{BACKGROUND}

This paper reviews current institutional and operational practices of Sovereign Wealth Funds (SWFs). The results of this study are based on analysis of a survey sent to members of the International Working Group of Sovereign Wealth Funds (IWG). These results were used as background information and input in the preparation of the Generally Accepted Principles and Practices for SWFs (GAPP), otherwise known as the "Santiago Principles", which were published on October 11, 2008. ${ }^{2} 3$

The summary of current SWF practices is based on responses to the SWF survey from 21 members of the IWG. The respondents are a diverse group, coming from six different continents, and are from countries having annual per capita incomes that vary from under US\$1,000 to over US\$80,000. The SWFs included in this analysis have been operating for various lengths of time; some were established as far back as the early 1950s, others as recently as a year ago.

Among the respondents, the majority of SWFs are funded out of mineral royalties (principally oil), while the remainder are funded from fiscal surpluses, as well as other sources including foreign exchange reserves and returns on fund investments. In a few cases, divestment proceeds and borrowing from markets have also played a role in asset accumulation.
Primary Source of Funds for SWFs (\% respondents)

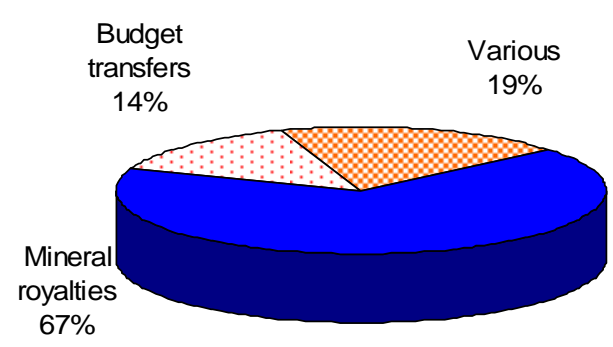

The survey findings provided below appear under three broad headings, and follow the structure of the Santiago Principles. These headings cover: (i) the legal framework, objectives and macroeconomic linkages; (ii) institutional framework and governance structure; and (iii) investment policies and risk management frameworks.

\footnotetext{
${ }^{2}$ The International Working Group of Sovereign Wealth Funds (IWG) was established on April 30, 2008, to identify and draft a set of principles that properly reflect their investment practices and objectives. For further information on the IWG see http://www.iwg-swf.org/index.htm.

${ }^{3}$ The IWG defines SWFs as special purpose investment funds or arrangements. Owned and created by the general government for macroeconomic purposes, SWFs hold, manage, or administer assets to achieve financial objectives, and employ a set of investment strategies which include investing in foreign financial assets. SWFs are commonly established out of balance of payments surpluses, official foreign currency operations, the proceeds of privatizations, fiscal surpluses, and/or receipts resulting from commodity exports. See IWG, 2008, Generally Accepted Principles and Practices-Santiago Principles.
} 


\section{LEgAL FrameWORK, OBJEctives, AND MACROECONOMIC LiNKAgES}

\section{A. Legal Basis and Form}

The legal basis and form in which SWFs are established varies from country to country. SWFs are often underpinned by specific legislation and, in a few cases, by the Constitution. A little more than half of the respondents indicate that they are established as legal entities separate from the state or the central bank, whereas the rest are not separate legal entities (pool of assets). SWFs falling under the former category either have a legal personality established under a specific constitutive law, or are a private corporation established under company law. SWFs falling within the latter category are usually controlled by the Ministry of Finance and operationally managed by the central bank or a statutory management agency. While many of these SWFs are also established by specific constitutive laws, some are established by general fiscal (budget or fiscal responsibility) laws, and one is established under the central bank law.

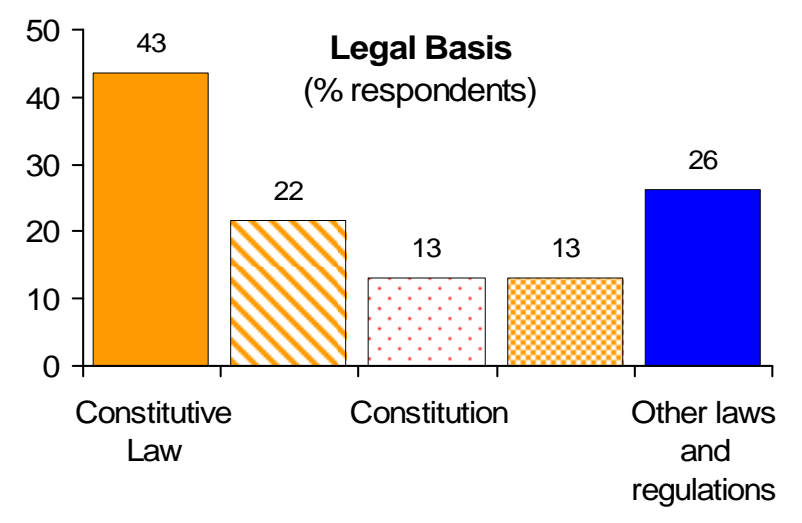

\section{Legal Form \\ (\% respondents)}

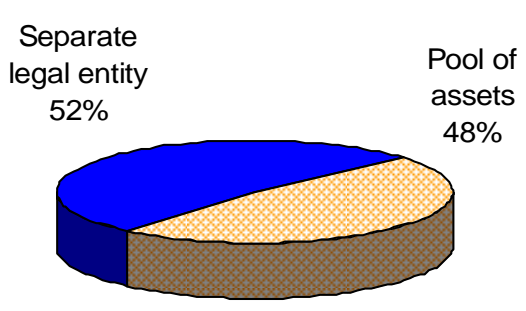

Typically, SWFs' constitutive legislation is publicly available. Constitutive laws, company laws, and budget laws under which SWFs are set up are publicly disclosed. One SWF that is established as a separate legal entity also publishes its charter of incorporation. In some cases where the SWFs are established as pools of assets, the management agreement between the ministry of finance and the central bank are publicly disclosed.

\section{B. Objectives and Macroeconomic Linkages}

The policy objectives of the SWFs are in part tied to the broad nature of their liabilities. SWF survey respondents generally indicate that they do not have direct liabilities, though some SWFs explicitly aim to cover expected future pension expenditures. Those SWFs without explicit future pension expenditures indicate that their fund is set up either to provide savings

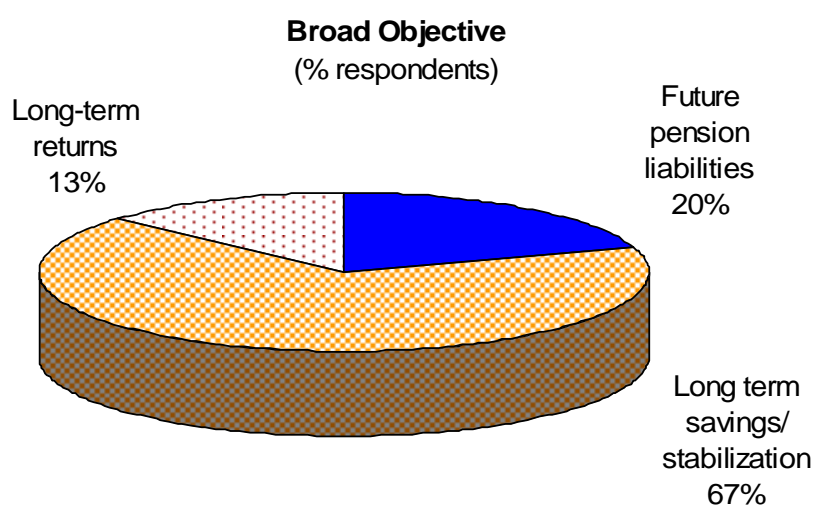


for future generations or fiscal stabilization (or both) or as reserve investment corporations. SWFs with future expected liabilities indicate that their primary objective is to cover the cost of these future expenditures. SWFs, and in particular those that act as legally-separate private corporations (see section below), also point out that their primary objective is to deliver longterm financial returns and effective management of entrusted assets. As the policy objectives of the SWFs are typically stated in their constitutive legislation, those objectives are publicly disclosed in most cases.

SWFs generally indicate that they do not engage directly in macroeconomic policies, but with two exceptions: (i) transfers to the budget for exceptional and targeted needs, and (ii) the drawdown of funds for transfer to the central bank in case of exceptional balance of payments or monetary policy needs. In one case, a separate short-term fund was set aside for such purposes.

\section{Funding and Withdrawal Rules}

Funding and withdrawal rules are specific to the type of SWF and set out in legislation. Thus, pension reserve funds (without explicit liabilities) typically have specific funding rules tied to meet future pension expenditure (for instance, a minimum amount is required per year to meet estimated future pension expenditure targets). Similarly, withdrawal rules for these funds take into account future estimated obligations. Except under exceptional conditions, funds cannot be withdrawn and require, for instance, targeted levels of the fund to be exceeded as well as Parliamentary approval.

Funding and withdrawal rules of other SWFs are usually tied to the source of the funds. For instance, fiscal stabilization funds are typically funded from revenue contingent deposit rules (i.e., exceeding a target), and withdrawal rules are typically crafted to meet specific budget deficits (i.e., in the event of a revenue shortfall) or funding needs, though not all SWFs specify what these may be. Reserve investment corporations are typically funded in relation to reserve adequacy requirements, and some funds have established asset trust contracts with sponsors that change periodically. Other differences in the rules exist: some keep capital and returns while others pay out targeted annual dividends to the owner (over fund targeted ceilings, taking into consideration operational expenses, etc.); some can invest directly in specific local investment projects, though respondents note that such transactions are reflected in the budget and are compliant with local and international government statistical rules (where indicated). 

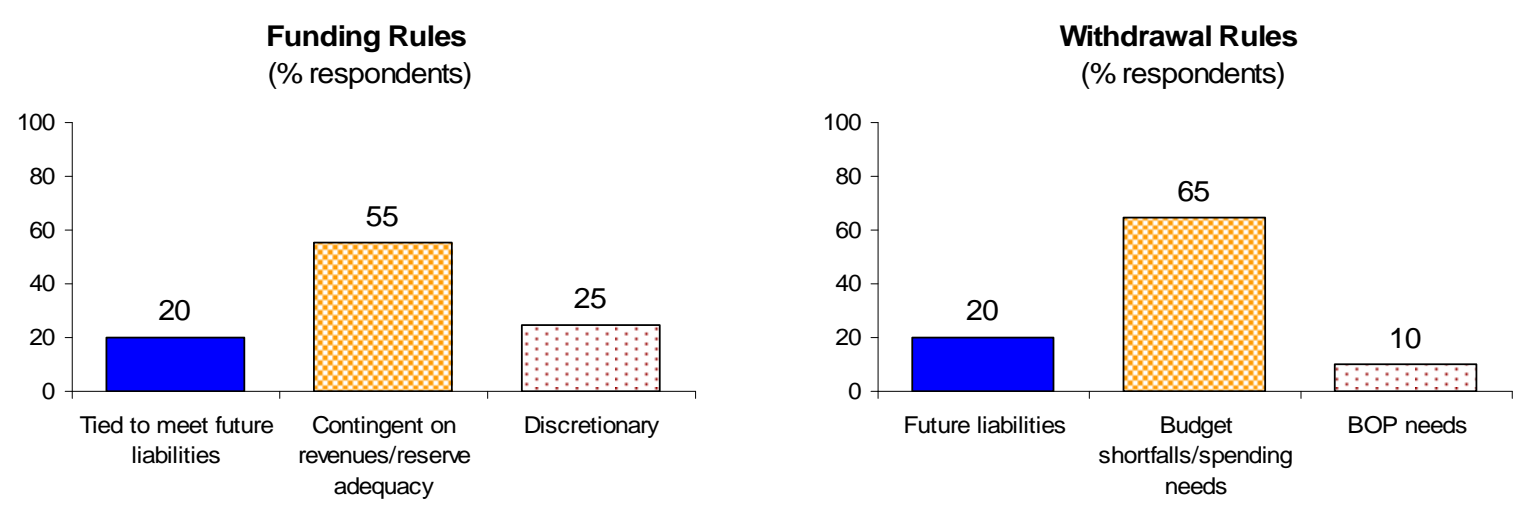

\section{Statistics Compilation and Reporting}

Respondents indicate that they produce economic and financial data on a regular basis. While some SWFs make information directly available to the public (for instance through annual and/or quarterly reports), others provide statistical data, such as on the size of the portfolio, its operation and performance indicators, only to the relevant national agencies. This largely depends on whether the fund is a separate legal entity (see section on integrity of operations below).

A majority of SWFs make their data available to compilers of macroeconomic statistics. ${ }^{4}$ Some of the responses elaborate on the level of detail in terms of sectorization, functional classification, and instrument breakdown, while the majority of these funds explicitly mention that their data provision is included in the Balance of Payments Statistics (BOP), International Investment Position (IIP), and/or Government Finance Statistics (GFS).
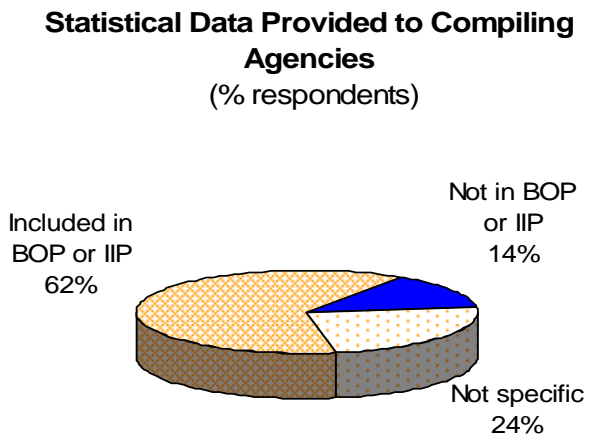

Some respondents mention that SWF data included in their BOP and IIP statistics cannot be distinguished because they have been consolidated with other items. This is in line with the current statistical methodological framework which does not provide for a separate recording of the external assets of SWFs. The draft version of the new IMF Manual on Balance of Payments and IIP Statistics (BPM6) allows for the voluntary public disclosure of SWFs' foreign assets not included in reserves. It also advises on the sectoral allocation of these government funds, depending on their institutional setting, and their functional classification, such as reserve, portfolio, direct investment and/or other investment.

\footnotetext{
${ }^{4}$ In some cases, the respondents are not specific on the regular provision of SWF data to compiling agencies.
} 


\section{INSTITUTIONAL FRAMEWORK AND GOVERNANCE STRUCTURE}

\section{A. Institutional Framework}

Institutional arrangements differ from one country to another. Investment policies, management and operational decisions are often centralized within the SWF or the central bank through a Board of Directors or Steering Committee. However, this is not always the

Who Determines the Investment Objectives?

(\% respondents)

case and responsibilities can be more

dispersed. For instance, in some cases where

the SWF is not a separate legal entity the

Minister of Finance or another official may be responsible for setting the specific investment objectives and benchmarks (often with the help of an advisory committee). In other casese.g., where the SWF is a separate legal entity-

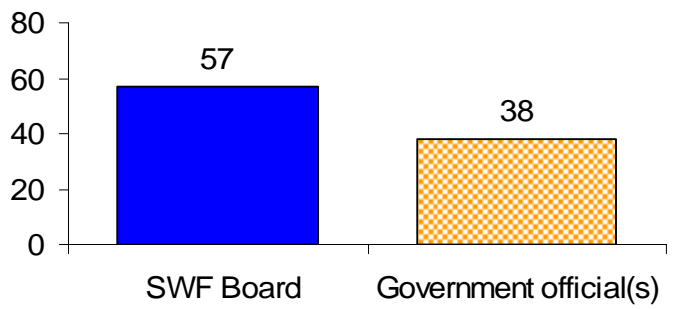
the high ranking official will be responsible for making investment decisions directly as a member of the governing body. Lines of reporting vary as well-SWFs report either to a supervisory council, the Minister of Finance or an elected official (President or Governor), or directly to Parliament.

Many respondents indicate that the respective institutional framework aims to provide the SWF with operational independence, while ensuring its accountability to the government and the public. In many cases this balance is achieved by establishing a separate legal entity or by entrusting management to the central bank, while requiring disclosure of audited financial reports and regular reporting to the Ministry of Finance and Parliament. Some respondents also note that ministerial directions to the SWF need to be reported to Parliament.

Where the SWF is a separate legal entity, operational independence is also typically embedded in the rules and procedures for appointment and removal of the members of the governing body. Though appointments to the governing body of SWFs (legally separate or otherwise) are frequently made by the Minister of Finance or other elected government official, these appointments are typically of long duration (5 years or more), and often include limits on the number of seats for government officials. ${ }^{5}$ Removal from the governing body can take place only under specified special circumstances, namely, if a member is incapable of continuing to perform the required function for health reasons or if convicted of an indictable offence. For those respondents that answered the survey question specifically, the rules for appointment and removal of members of the governing body are established by legislation. Where the SWF is not a separate legal entity, the governing body may comprise

\footnotetext{
${ }^{5}$ While some SWFs indicate that they have limits on the number of government officials in the governing body, others do not have such limits. In cases where there are restrictions on government representatives in the governing body, the number of seats is low (minority). In some cases there is no official representation in the governing body at all.
} 
only government officials. In such cases, operational independence is sought through the delegation of responsibility for the SWF's operational management to the central bank or a statutory management agency.

\section{Governing Body Representation} (\% respondents)

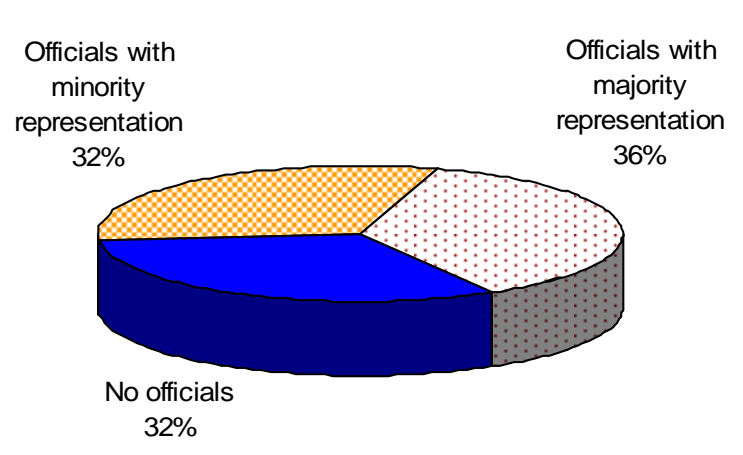

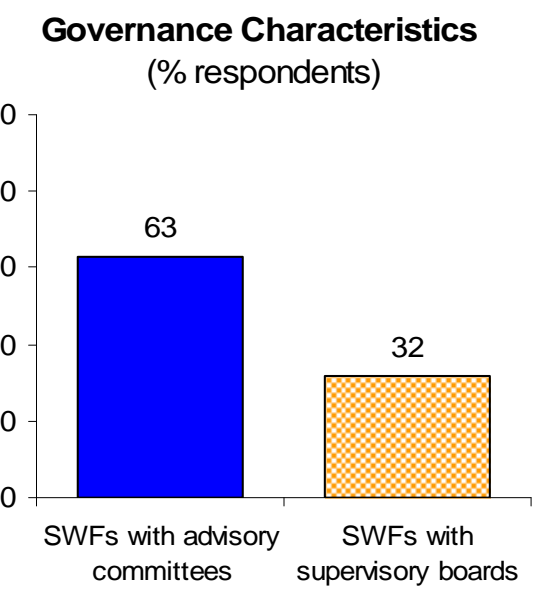

In cases where SWFs are established as separate legal entities, they are managed by a Board of Directors, which typically comprises five to nine members. Board members are selected on the basis of their expertise in investment management, corporate governance, finance and economics. The Board is chaired by a Chief Executive Officer (CEO), who is either selected externally (i.e., by the Minister of Finance) or by the Board. Some SWFs have advisory committees to assist and advise the Board in such areas as investment policies, audit and risk functions, corporate operations (including employee and remuneration policies), and management performance. Some SWFs also have a Supervisory Board or Committee responsible for control and oversight purposes.

The internal governance structure of many SWFs-particularly those that are established as separate legal entities-is similar to the typical structure of private corporations. The head of the SWF is responsible for executing the assigned mandate (i.e., implement and in many cases develop the investment policies) and for the employment and management of staff. The SWF-head typically has a cadre of subordinate executives with specific functional responsibilities (i.e., a Chief Operating Officer, Chief Financial Officer, and a Chief Investment Officer). The structure then branches out into various functional clusters, which are headed by managers. In the case of SWFs that are established as pools of assets without separate legal personality the agencies responsible for the SWFs' operational management may have varying structures.

\section{B. Accountability}

Accountability to the legislature is vested in the entity that owns or manages the SWF. In those cases where the SWF is not a separate legal entity, the Ministry of Finance reports to Parliament on the activities of the fund. The report to Parliament-which is commonly presented annually but in one case is provided quarterly-contains audited financial statements of the fund either separately or as part of the government financial statements, or the audited financial statements of the managing entity. 
Accountability to the Legislature

(\% respondents)

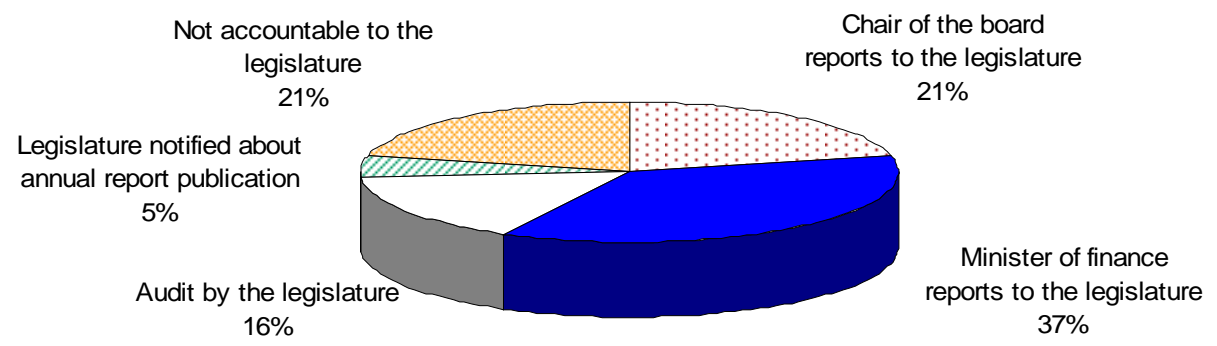

Parliaments can exercise varying levels of scrutiny over SWFs that are managed by a legal entity separate from the Ministry of Finance or the central bank. In most cases, the report of the SWF, including its audited financial statements, is submitted to Parliament or a parliamentary committee annually or upon request by the committee. The Boards of these SWFs are typically required to prepare annual business plans, against which they are held accountable in the annual reports. In one case, a designated parliamentary committee approves the business plan and the annual report and communicates to the public on the activities of the SWF and its performance results.

In cases where the SWFs are separate legal entities, another layer of accountability may be added by the Minister of Finance. In these cases, the accounts of the SWF may be fully consolidated with the government's accounts and the Minister of Finance is responsible for the investments of the fund. The Minister of Finance may hold the Board of the SWF accountable for the SWF's statutory objectives and investment mandate, or the consistency of the Board's investment strategy with the government's investment mandate. If satisfactory performance in regard to these objectives and mandate is lacking, the Minister of Finance may terminate the appointment of the Board members.

Where the SWF operates as a corporation under general company law, it is typically accountable to its shareholder-the government represented by the Minister of Finance-for its performance. The Minister of Finance ensures that the Board is competent to oversee the activities of the SWF, but the government operates at arm's length and does not get involved in the business and investment decisions of the SWF. The SWF typically publishes an annual report and maintains a website to inform the public.

All SWFs prepare and present their financial statements according to a prescribed set of accounting standards. Some SWFs state that their financial statements are in full accordance with the IFRS. Others indicate that they apply accounting standards which they consider "equivalent to" or "materially" the same as the IFRS, or refer to the preparation of their financial statements in line with "International Public Sector Accounting Standards" (IPSAS), which take account of the characteristic features of the public sector. Another group indicates that they are in the process of converging towards full IFRS compliance. Finally, some SWFs apply their own national, generally accepted accounting principles (national GAAP) or national Financial Reporting Standards, and three SWFs specifically mention 
market-based measurement. A few SWFs describe minor exceptions to the accounting standards that are in place in terms of presenting or publishing the data. Some SWFs emphasize that the responsibility and requirement to prepare and accurately present their financial statements are constituted by law, setting the legal requirements for the preparation and presentation of the financial report according to appropriate accounting policies and free from material misstatements.

Applicable Accounting Standards

(\% respondents)

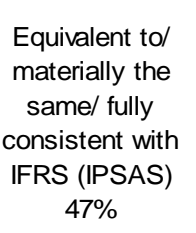

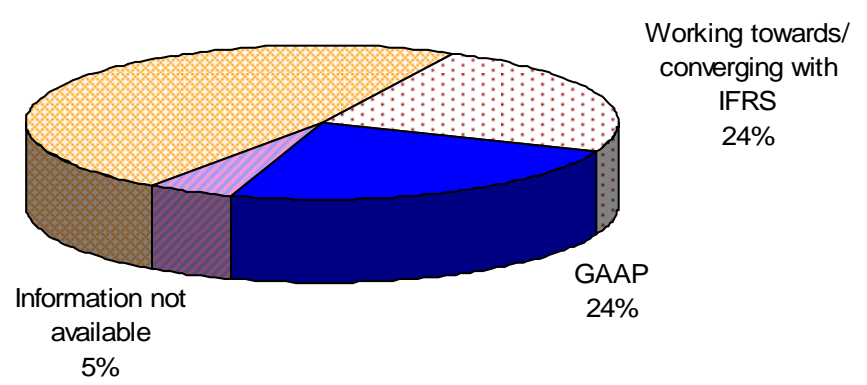

SWFs' financial statements are subject to the professional judgment of internal and appointed external auditing entities, although with varying institutional settings. Some SWFs explain that the financial statements are audited according to audit standards that are almost identical to, or are currently undergoing a harmonization toward, internationally recognized audit standards. While auditing focuses largely on financial information, the process in some SWFs also involves an evaluation of management activities, e.g., in terms of assessing the effectiveness and efficacy of risk management tools, as well as an assessment of the efficiency of internal control systems.

All respondents indicate that they have internal audit arrangements in place. In some SWFs, internal auditing is undertaken by independent auditors, such as accounting firms or temporarily appointed statutory auditors. Other SWFs have established internal audit divisions to strengthen in-house commitments to internal control and supervision arrangements in covering various business areas of the SWF. Internal auditors or internal control units assess and review the funds' activities in accordance with adopted legislation; oversee compliance with the respective investment guidelines in terms of profitability and risk exposure; provide regular reports of their findings; and make recommendations to internal bodies, often referred to as internal Audit Committees in charge of oversight and monitoring compliance and internal audit functions. When the SWF has no formal internal audit entity in place, the auditing function may be assigned to another department within the SWF that has duties similar to the internal audit functions.

External audits are in most cases performed by independent, internationally recognized accounting firms. Few SWFs have their accounts audited by Auditor Generals, another independent government agency or the Ministry of Finance itself. Audit procedures include an evaluation of the fund's administration, a review of the Board's judgments and decisions, and an assessment of financial and management controls. SWFs put emphasis on the 
temporary appointment of the external auditing entity to ensure independence, regularity of the audit (usually annually), the availability of audited reports to the public and compliance with the International Auditing Standards.

\section{Integrity of Operations}

In general, SWFs share common standards governing the conduct of personal financial affairs and have similar rules to prevent exploitation or misuse of funds by members of the Board, management and staff. These are either set out in separate legislation and/or codes of ethics, codes of conduct and manuals adopted by the SWFs that address insider dealing, conflicts of interest, disclosure policies, systems of monitoring and detecting unethical behavior and fraud, and mechanisms for properly addressing and managing instances of fraud. While specific standards within these broad categories differ from one SWF to the other, some common practices reported by SWF respondents include requiring financial reporting and disclosure of investments on a regular basis, prohibiting the acceptance of gifts (other than meals or token gifts), and having a compliance officer to ensure compliance with applicable laws, regulations and standards.

\section{Legislation governing SWFs usually requires public disclosure of information about} their institutional structure and operations. Most commonly, the legal and the institutional framework of the SWFs is publicly disclosed, but other information may not be provided. More than 50 percent of the respondents indicate that they publish annual audited financial statements, at least a summary of their asset allocation - in some cases even the actual portfolio - and performance information. Furthermore, a significant number of the respondents publish unaudited statements quarterly or monthly, and one SWF publishes the unaudited value of the fund daily.

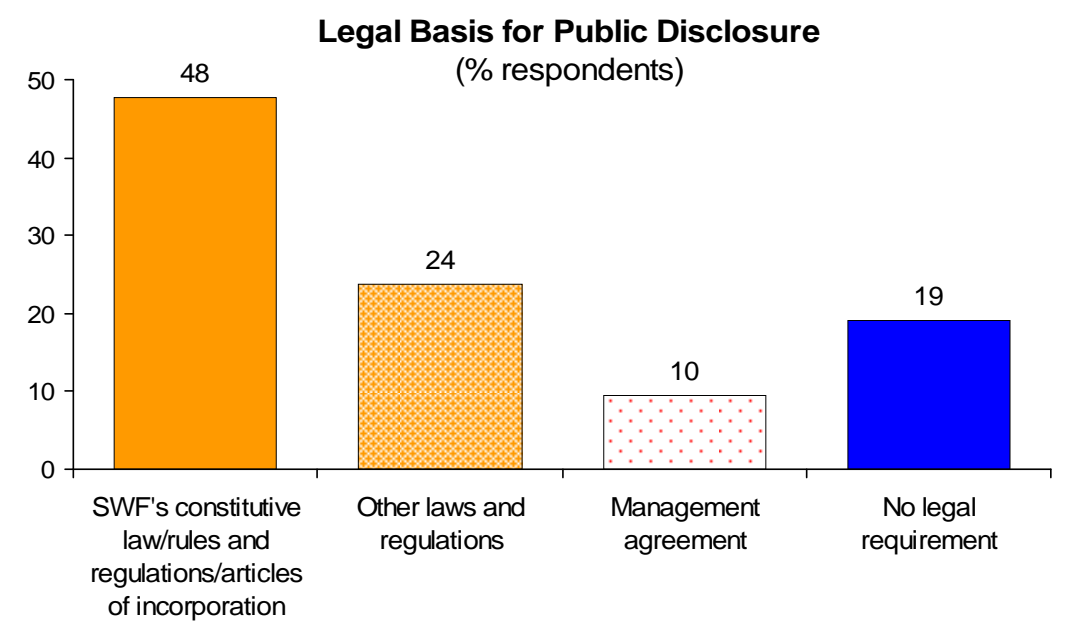

Public disclosure by SWFs that are not separate legal entities varies significantly. The assets, revenues, and expenses are typically published by the agency responsible for the management of the SWF. One SWF publishes extensive information describing the objectives of the fund, its institutional framework, agency arrangements, investment policy (including a broad discussion of the implementation of ethical guidelines), risk management framework, audited financial statements and accounting policies, actual portfolio 
composition (including a complete list of all assets held by the fund and the manner in which it has exercised its voting rights), and performance data.

\section{SWFs that are established as separate legal entities are typically required to publish}

detailed annual reports, including information about their objectives and legislative basis, institutional arrangements and governance structure, investment policies and risk management framework, audited financial statements, and performance data. The information is disclosed through the internet or by the virtue of disclosure of information submitted to Parliament.

SWFs that are separate legal entities are not generally required to publish their actual portfolio information. However, in one case the SWF is required to disclose investment information verifying that its investment policy is consistent with the United Nations Principles for Responsible Investment. ${ }^{6}$ On the other hand, a number of SWFs strive for greater transparency beyond the statutory obligations. These SWFs publish the current asset allocation-including for example, real estate, bonds, and stock holdings-Board minutes, and unaudited statements at higher frequency than required by the statute for audited statements.
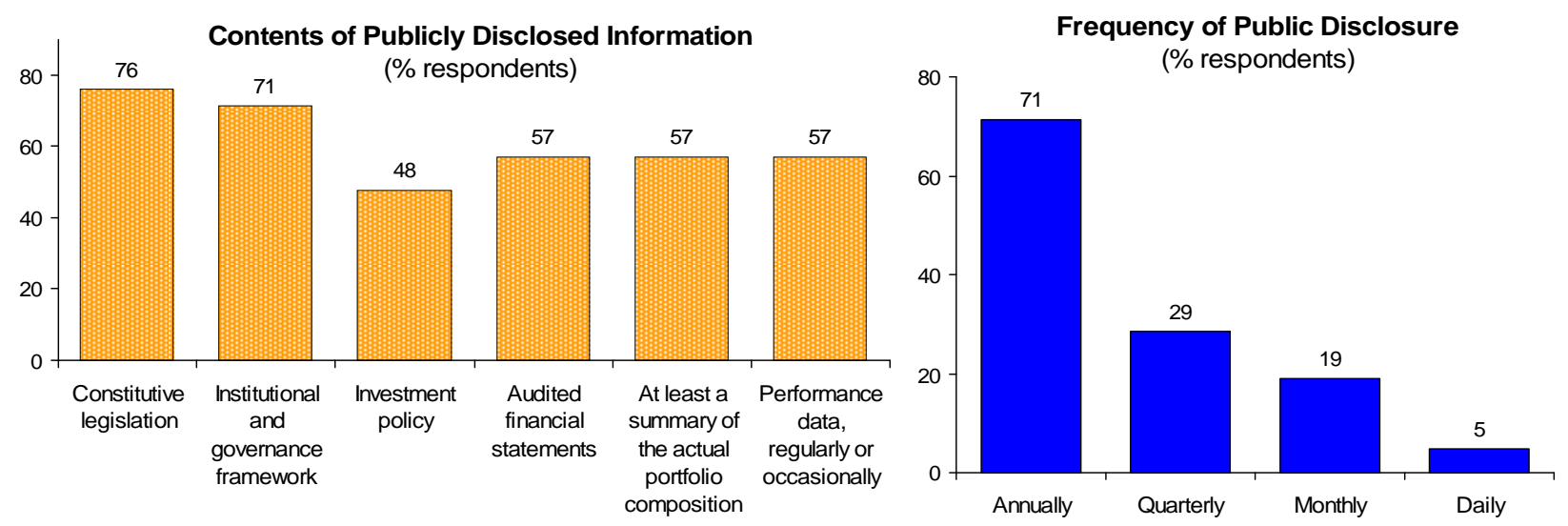

\footnotetext{
${ }^{6}$ Institutional investors who have adopted these principles consider that environmental, social, and corporate governance issues can affect the performance of investment portfolios and the application of the principles can help better align investors with broader objectives of society.
} 


\section{INVESTMENT Policies AND Risk ANAgEMENT FrAMEWORKS}

\section{A. Investment Policies}

The majority of respondents indicate that they have specific investment objectives. While a number of funds maximize returns relative to a benchmark, others have absolute return objectives, but the risk constraint plays an important role as the feasible set of returns changes over time (after the objective has been set). The investment objectives are either explicitly stated by the owner of the funds (i.e., the government)especially when the SWF is not a separate legal entity — or by the manager of the funds when the owner or applicable law formulates more general investment objectives. Several

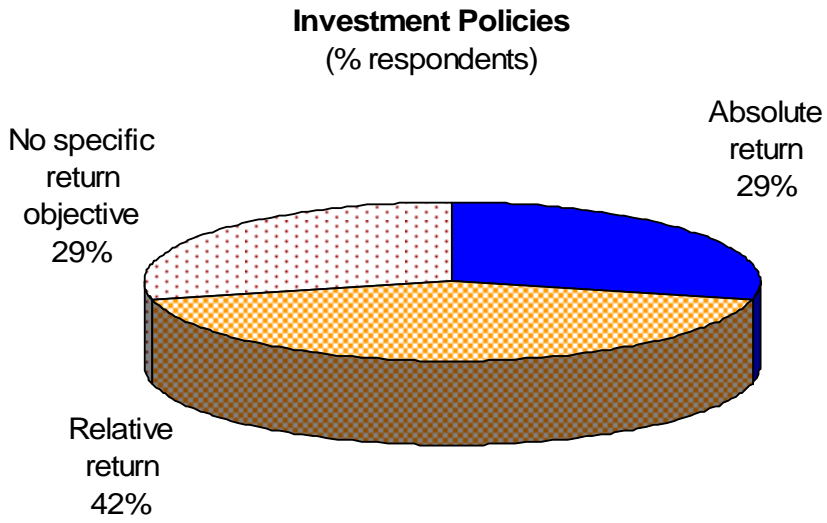
respondents indicate that they do not have specific return objectives aside from a general objective (i.e., of seeking long-term financial returns). About half of the respondents indicate that they disclose publicly the specific investment objectives of their SWFs.

Some SWFs indicate that they use an asset approach in determining their investment strategy, and one SWF explicitly states that it uses an asset-liability approach. The investment strategy is typically derived using a mean variance asset allocation model. In some cases, the return objective and risk parameters are formulated relative to a benchmark based on a market index (see above). Asset class and regional weights are also set against a benchmark. Most respondents indicate that the asset allocation has a long-term focus but is reviewed regularly - every one to two years. Performance is also reviewed regularly, in many cases daily, and is assessed in relation to the index. Portfolio rebalancing is based on the maximum tracking error deviation and is done at regular time intervals (weekly, bi-weekly, monthly, or quarterly), but may also be triggered by large market movements.

Investment strategies vary from traditional to more advanced. SWFs that are not separate legal entities have relatively traditional asset allocations, mostly limited to highly rated government securities; only a few are investing in equity and taking on more credit risk. Other SWFs use more alternative asset classes, with benchmarks including 40-70 percent equity, 4-10 percent private equity funds, 13-40 percent fixed income, $2-5$ percent infrastructure, 2-5 percent commodities, and 8-10 percent real estate. One SWF acknowledges that it has the option of taking concentrated risks and is open at all times to increase, reduce, or divest its holdings. 


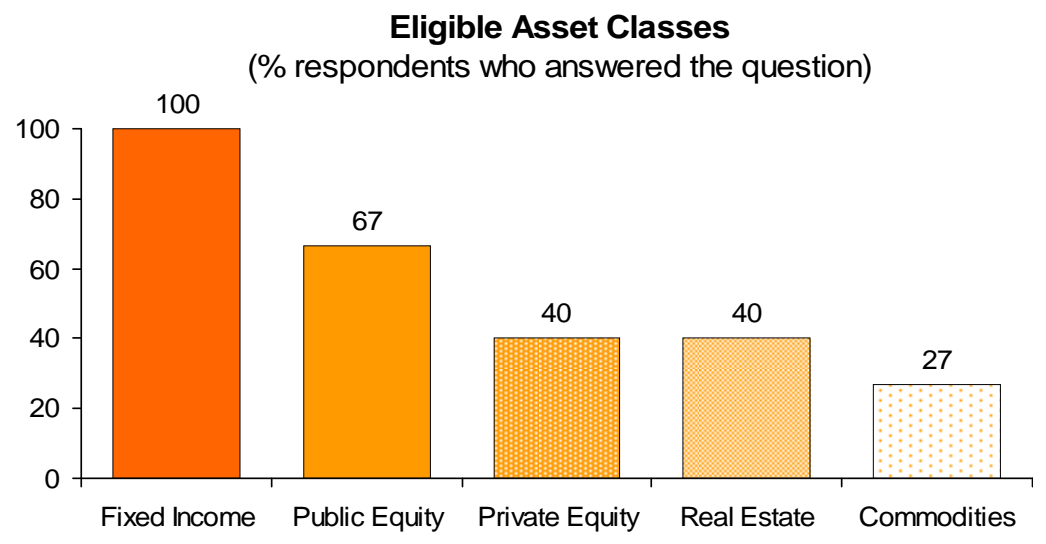

B. Risk Management Frameworks

Risk objectives are typically determined by the owner or the governing body of the SWF. While broad principles are generally established within the law or by the owner of the funds, more specific risk management objectives are typically laid out by the SWF's managers. SWFs indicate that these are usually set as tracking error limits or risk bands relative to a benchmark index for tactical management. About half of the survey respondents report that they disclose publicly elements of the risk management policy of their SWFs.

\section{The most common risk measures and methods to manage financial risks are credit} ratings, value-at-risk models, tracking error, duration, and currency weights. Credit risk is usually constrained by limits on exposure to different tiers of credit and issuers. Liquidity risk is mitigated by investing primarily in securities traded in recognized exchanges and requirements for portfolio diversification of the asset managers. Currency risk is controlled by a foreign currency hedging policy for the portfolio and limits on currency exposure relative to the benchmark for individual asset managers. Some SWFs indicate that overall risk levels are subject to stress testing.

Risk Measures

(\% respondents)

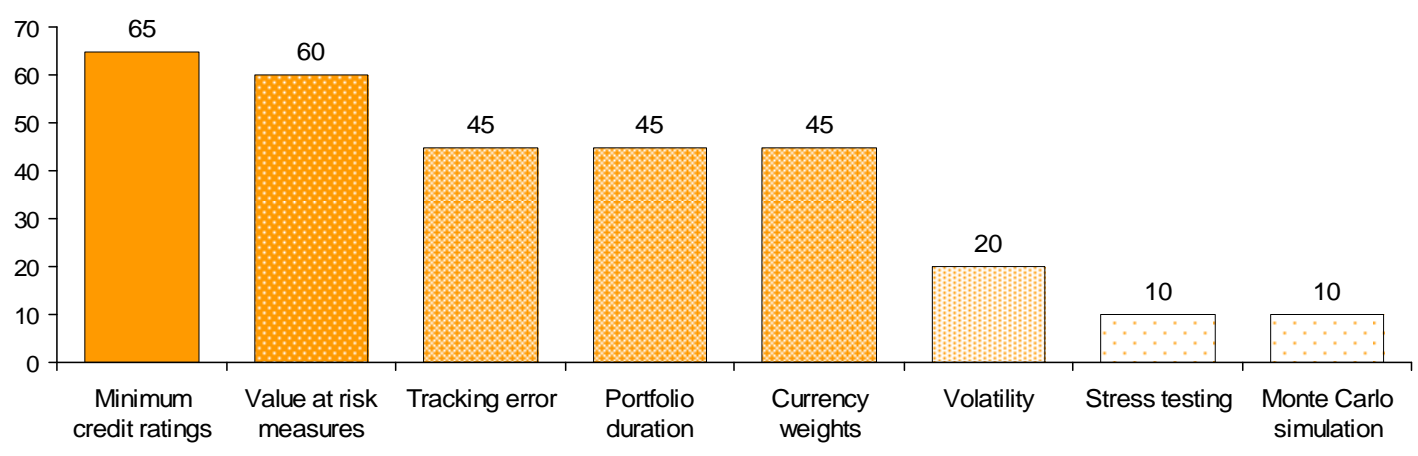


In addition to tactical risk limits, SWFs typically observe general constraints on investment classes and instruments. Most SWF respondents note that they are not allowed to borrow or use leverage. Several SWFs point out that they invest in certain asset classes that use leverage (e.g., private equity and multi-strategy funds) or employ derivatives for the purpose of protecting the value or return of their investments. In addition, many SWFs have established limits on stakes that they can hold in companies, the types of investment they can hold (e.g., investment grade assets only), and/or on other characteristics of their portfolio (e.g., currency or country).
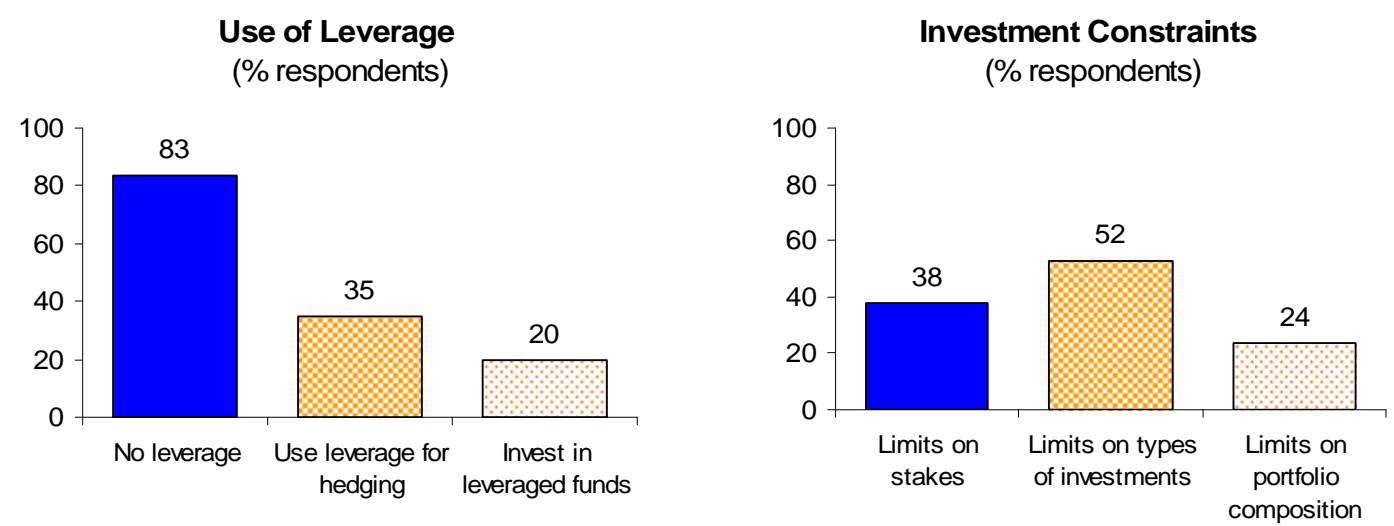

Several SWFs point out that operational risk is controlled through separation of responsibilities, including front, middle, and back offices. SWFs also mitigate operational risk through the implementation of codes of conduct and policies on conflict of interest for staff and the governing body, regular reconciliation of accounts, and regular and active audits. Several SWFs note that they use back-up facilities, global custodian services, and business continuity plans, as well as regularly (annually) reviewed operating manuals, to mitigate operating failures. One SWF also monitors operational risk

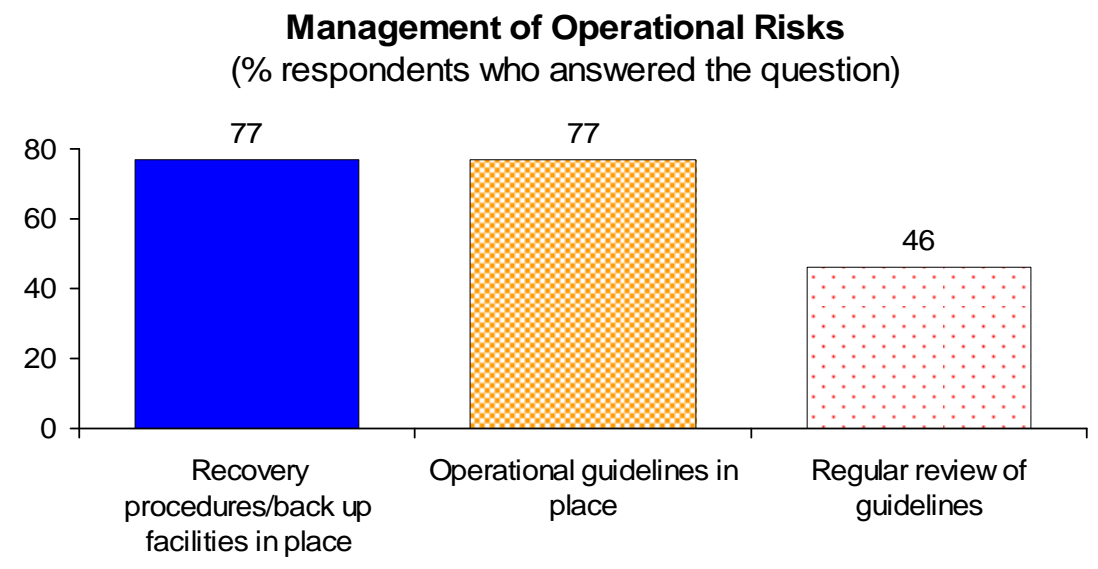
with early warning indicators and by assigning direct responsibility for operational risk monitoring to line managers. Finally, some SWFs note the use of workflow automation and frequent — even daily — reports by the middle office to management to ensure timely communication and early warning of operational risks.

\section{External Asset Managers}

The proportion of assets managed by external asset managers varies widely across the respondents in line with the adopted investment strategies. Only two of the responding 
SWFs do not use external managers at all, although one of them is actively considering this possibility. In contrast, some SWFs have assigned most or all of their assets to external asset managers. External managers are used in cases where the managing agency does not have sufficient expertise in managing specific assets, or where it is not cost-effective to manage them in-house due to the external mangers' economies of scale and extensive research capabilities. SWFs indicate that they mandate the external managers with both active and passive management, while only passive management remains in-house.

External managers are typically approved by the Board of the SWF. The evaluation of the external managers is based on the approved investment strategy, is considered an investment decision, and is subject to standard procedures. Although performance appears to be the main basis for appointment and removal of external managers, some SWFs indicate that the organization, the personnel team, and the investment philosophy of the external managers are also

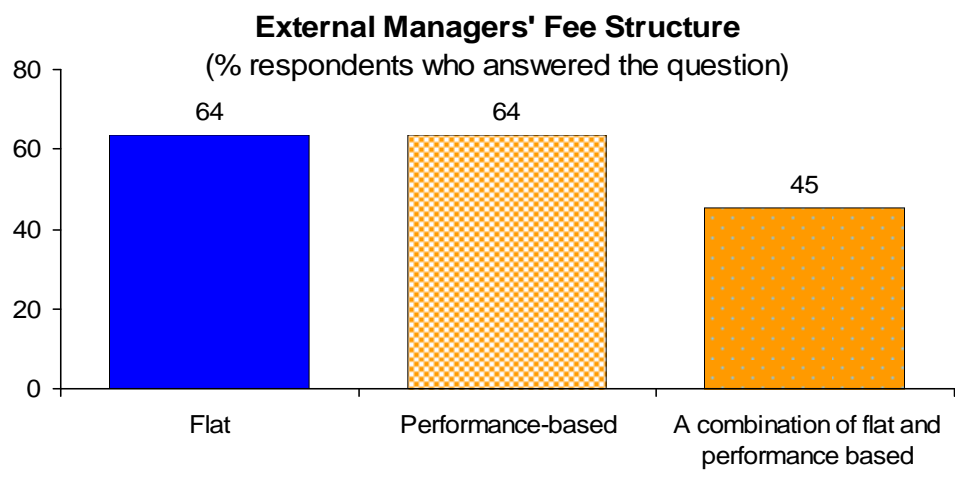
considered important factors. Fees could be flat, performance-based, or a combination of both. In some cases, an external manager policy is in place, but is not publicly available. Some SWFs publish details about their external managers. Consultants are not commonly used to assist in the selection process, except by some smaller SWFs or for specific advice in specialized areas.

\title{
D. Other Information
}

\begin{abstract}
About a third of the respondents are currently in the process of reviewing or initiating changes in their organizational structure (governance, staffing) or in their existing strategies (investment policy). Some SWFs have been drawing on the assessment and recommendations provided by designated advisory commissions or by private advisory service companies entrusted with the evaluation of the funds' organizational structure and operational procedures. In this respect, a number of SWFs are considering requesting changes in the relevant legal framework, so as to better align it with operational and other requirements. A number of funds also mention the value added that expertise from external managers can provide by helping to engage in more active asset management with the objective of achieving higher returns and at the same time improving risk diversification. This is expected to be achieved by expanding the benchmark, broadening the investment range, for instance by investing a portion of the Fund in real estate, and in general through opening the fund to more asset classes, and also by spreading investment activities more globally.
\end{abstract}




\section{E. Conclusion}

Current practices of SWFs vary considerably, reflecting the diversity of these institutions. These differences derive from the nature of the SWF (i.e. their original intent) as well as its legal personality. Thus, for instance, fiscal stabilization funds will operate differently from pension reserve funds or reserve investment corporations: they will have different policy objectives, funding and withdrawal rules, institutional frameworks and accountability arrangements, and as a consequence differing investment policies and risk management frameworks.

At the same time, practices within various groupings or types of SWFs tend to be more similar. For instance, pension reserve funds, because of their common objectives tend to have more comparable practices. Similarly, SWFs that are established as legally-separate entities share some common practices and features, as do SWFs that are not legally separate. The former tend to have similar institutional frameworks and an internal governance structure akin to that of a private corporation; publish detailed annual reports; and tend to invest more in alternative asset classes. By contrast, the governing body of SWFs that are not legally separate may comprise only government officials; generally have less financial disclosure, though this varies significantly; and have relatively traditional asset allocations.

That being said, SWFs as a group also share some broader common practices. As has been shown, SWFs generally do not engage directly in macroeconomic policies; make their data available to compilers of macroeconomics statistics; have internal audit arrangements in place and have external audit conducted by independent audit firms; have common standards to prevent exploitation or misuse of funds; require public disclosure about their institutional structure and operations; and have established risk management practices and observe constraints on investment classes and instruments.

The diversity of practices for the SWF group as a whole, but similarities within SWFtypes, suggests that while practices will continue to evolve, the fundamental objectives of different types of SWFs will continue to shape their practices going forward. Thus, SWFs - particularly newer ones or those being established-will be looking at the Santiago Principles for guidance, while also closely examining the practices of established SWFs with similar objectives to help guide their own. 


\section{REFERENCES}

Australia, Future Fund, 2007, Annual Report 2006-2007. Available via the Internet: http://www.futurefund.gov.au/ data/assets/pdffile/0014/1409/Future_Fund_Annual _Report_2006-07_internet.pdf

Australia, Office of Legislative Drafting and Publishing, 2006, Future Fund Act. Available via the Internet:

http://www.comlaw.gov.au/ComLaw/Legislation/ActCompilation1.nsf/0/634963F316 229805CA25736E0080082B/\$file/FutureFundAct2006.pdf

Azerbaijan, Committee on The Extractive Industries Transparency Initiative, 2007, Independent Accountants' Report for the Year Ended 31 December 2007. Available via the Internet: http://www.oilfund.az/pub/uploads/swbtPV2M.pdf

Azerbaijan, State Oil Fund of the Republic of Azerbaijan, 2007, Annual Report. Available via the Internet: http://www.oilfund.az/pub/uploads/d5S3hY0X.pdf

Azerbaijan, The President of the Azerbaijan Republic, 1999, Decree \#240 on Establishment of the State Oil Fund of the Republic of Azerbaijan," (Baku, 29 December). Available via the Internet: http://www.oilfund.az/en/content/13/9

Azerbaijan, The President of the Azerbaijan Republic, 1999, Decree-Regulations Of The State Oil Fund Of Azerbaijan, (Baku, 29 December). Available via the Internet: http://www.oilfund.az/en/content/12/79

Botswana, 1996, Bank of Botswana Act, in Government Extraordinary Gazette. Available via the Internet: http://www.bankofbotswana.bw/files/attachments/o2061406223.html

, Bank of Botswana, 2007, Annual Report. Available via the Internet: http://www.bankofbotswana.bw/files/attachments/preliminaries,\%20statutory\%20rep ort\%20and\%20botswana\%20economy\%20in\%202007.pdf

Canada, Alberta Government, 1976, Alberta Heritage Savings Trust Fund Act. Available via the Internet: http://www.qp.gov.ab.ca/Documents/acts/A23.CFM

Canada, Alberta Heritage Savings Trust Fund, 2008, 2007-08 Annual Report. Available via the Internet: http://www.finance.alberta.ca/business/ahstf/annrep08/report.pdf

Canada, Alberta Heritage Savings Trust Fund, 2008, 2008-2011 Business Plan. Available via the Internet: http://www.finance.alberta.ca/publications/budget/budget2008/heritage.pdf

Chile, Financial Committee, 2007, Annual Report. Available in Spanish via the Internet: http://www.hacienda.cl/publicaciones.php?opc=showContenido\&url=\&id=12673\&na v_id=10262\&actual $=10262$ 
Chile, Ministry of Finance, 2008, Report on the Quarterly Operations of the Pension Reserve Fund (April-June). Available in Spanish via the Internet:

http://www.hacienda.cl/publicaciones.php?opc=showContenido\&url=\&id=13009\&na $\underline{\text { v_id=10291\&actual=10291 }}$

, 2008, Report on the Quarterly Operations of the Economic and Social Stabilization Fund (April-June). Available in Spanish via the Internet:

http://www.hacienda.cl/publicaciones.php?opc=showContenido\&url=\&id=13010\&na v_id=10293\&actual $=10293$

Chile, National Congress, 2006, Law N20.128_Fiscal Responsibility Law. Available in Spanish via the Internet: http://www.bcn.cl/leyes/pdf/original/253645.pdf

China, Articles of Association of China Investment Corporation: An Abstract. Available via the Internet: http://www.china-inv.cn/cicen/governance/articles.html

Ireland, National Pensions Reserve Fund, 2008, 2007 Annual Report (June). Available via the Internet: http://www.nprf.ie/Publications/AnnualReport2007.pdf

Ireland, Office of the Attorney General, 2000, National Pensions Reserve Fund Act. Available via the Internet: http://www.irishstatutebook.ie/2000/en/act/pub/0033/print.html

Korea, 2005, Korea Investment Corporation Act (March). Available via the Internet: http://www.kic.go.kr/en/images/in/01.KICACT.pdf

Korea, Korea Investment Corporation, 2007, Annual Report. Available via the Internet: http://www.kic.go.kr/program/kicboard/view.jsp?did=en\&id=ein060000\&no=171 , 2007, Audit Report. Available via the Internet: http://www.kic.go.kr/program/kicboard/proc.jsp?id=erl020100\&mode=download\&no $=159$

, 2008, Investment Policy Statement (January). Available via the Internet: http://www.kic.go.kr/en/images/ki/KIC_IPS_Eng_080114.pdf

Korea, Ministry of Finance and Economy, 2005, Articles of Incorporation of Korea Investment Corporation. Available via the Internet: http://www.kic.go.kr/en/images/in/03.KIC\%20AOI_revised.pdf

Kuwait, 1976, Law Decree No. 106 for the Year 1976 concerning the Reserves for Future Generations. Available via the Internet: http://www.kia.gov.kw/NR/exeres/5D28BFE9-063D-472D-ABB1E28A86AC1D37.htm

Mexico, Congress of Mexico, 2006, Federal Budget and Fiscal Responsibility Law, Available in Spanish via the Internet: http://www.cddhcu.gob.mx/LeyesBiblio/pdf/LFPRH.pdf 
New Zealand, 2001, New Zealand Superannuation and Retirement Income Act 2001 No. 84 (10 September 2008). Available via the Internet: http://www.legislation.govt.nz/act/public/2001/0084/latest/096be8ed802a9265.pdf

New Zealand, Guardians of New Zealand Superannuation, 2008, Annual Report. Available via the Internet:

http://www.nzsuperfund.co.nz/files/2008\%20Annual\%20Report\%20Editorials.pdf

New Zealand, Guardians of New Zealand Superannuation, 2008, Financial Statements. Available via the Internet: http://www.nzsuperfund.co.nz/files/2008\%20Annual\%20Report\%20Financials.pdf

New Zealand, Guardians of New Zealand Superannuation, 2008, Statement of Intent. Available via the Internet: http://www.legislation.govt.nz/act/public/2001/0084/latest/096be8ed802a9265.pdf

Norway, 2005, Government Pension Fund Act (No. 123 of 21 December). Available via the Internet: http://www.regjeringen.no/en/dep/fin/Selected-topics/The-GovernmentPension-Fund/the-guidelines-for-the-management-of-the.html?id=434605

Norway, Ministry of Finance, 2008, “On the management of the Government Pension Fund” in The National Budget for 2008, Chapter 5. Available via the Internet: http://www.regjeringen.no/upload/FIN/Statens\%20pensjonsfond/Chapter\%205-3.pdf , 2008, Report No. 16 (2007-2008) to the Storting. On the Management of the Government Pension Fund in 2007. Available via the Internet: http://www.regjeringen.no/pages/2064594/PDFS/STM200720080016000EN_PDFS.pdf

Norway, Norges Bank Investment Management, 2008, 2007 Annual Report. Available via the Internet: http://www.norgesbank.no/Upload/NBIM/Reports/2008/Annual\%20report\%202007.pdf

Russia, Ministry of Finance, 2007, Budget Code (April). Available in Russian via the Internet: http://www1.minfin.ru/ru/reservefund/legalframework/index.php?id4=5809 , 2007, Budget Code (April). Available in Russian via the Internet: http://www1.minfin.ru/ru/reservefund/legalframework/index.php?id4=5809

Singapore, 1965, Constitution of the Republic of Singapore, Available via the Internet: http://statutes.agc.gov.sg/non_version/cgi-bin/cgi_retrieve.pl?\&actno=RevedCONST\&date=latest\&method=part

Singapore, Government of Singapore Investment Corporation, 2008, Report on the Management of the Government's Portfolio for the Year 2007/08. Available via the Internet: http://www.gic.com.sg/PDF/GICreport0708_Full.pdf 
Singapore, Temasek Holdings, 2008, Temasek Review. Available via the Internet: http://www.temasekholdings.com.sg/TemasekReview/2008/pdf/TR2008\%2018-0808\%20Bookmarked.pdf

Timor Leste, 2005, Petroleum Fund Law. Available via the Internet: http://www.bancocentral.tl/Download/Publications/Petroleum_Fund_Law.en.pdf

Timor Leste, Banking and Payments Authority, 2005, Operational Management Agreement. Available via the Internet: http://www.bancocentral.tl/Download/Publications/Management_Agreement.En.pdf , Banking and Payments Authority, 2006, Annual Report 2005-2006. Available via the Internet: http://www.bancocentral.tl/Download/Publications/PF_Annual_Report_Final_en.pdf

Trinidad and Tobago, 2007, Act No. 6: Heritage and Stabilization Fund Act. Available via the Internet: http://www.finance.gov.tt/documents/77.pdf

Trinidad and Tobago, Central Bank of Trinidad and Tobago, 2007, Annual Report. Available via the Internet: http://www.central-bank.org.tt/publications/issues/ar1217361576.pdf

U.S.A., Alaska Permanent Fund Corporation, 2004, Bylaws, Available via the Internet: http://www.apfc.org/home/Media/theapfc/2004_9_bylaws.pdf

, Alaska Permanent Fund Corporation, Report Archive, Available via the Internet: http://www.apfc.org/home/Content/reportspublications/reportArchive.cfm

U.S.A., Alaska, 1977, Alaska Constitution and Law Pertaining to the Permanent Fund, Available via the Internet: http://www.apfc.org/home/Content/fundlaw/constAndLaw.cfm 